DOI https://doi.org/10.30525/978-9934-26-073-5-1-18

\title{
О ДЕРИВАЦИОННЫХ ДИНАМИЧЕСКИХ ПРОЦЕССАХ В СОВРЕМЕННОМ РУССКОМ И УКРАИНСКОМ ЯЗЫКАХ
}

\author{
Шепель Ю. А. \\ доктор филологических наук, профессор, \\ академик Национальной академии наук высшего образования Украины, \\ профессор кафедры перевода \\ и лингвистической подготовки иностраниев \\ Днипровского наџионального университета имени Олеся Гончара \\ 2. Днипро, Украина
}

Динамические процессы в словообразовании, наблюдаемые в настоящее время в русском и других славянских языках, совершенно справедливо можно отнести к числу приоритетов в дериватологии, потому как именно динамический подход к изучению лингвистических объектов позволяет обнаруживать различные типы колебаний в функционирующей системе языка и способствует выявлению общих тенденций ее развития. По мнению 3. И. Резановой, в языковой онтологии когнитивная и коммуникативная функции «существуют в неразрывном единстве, взаимно обусловливая друг друга: любая коммуникация когнитивно детерминирована, а человеческая когниция глубинно коммуникативна» [1, с. 196-197]. Замечу, система словообразования русского, украинского, как, впрочем, и английского, языков очень подвижна, поэтому она достаточно быстро откликается на любые изменения в жизни общества, когда модификации в сфере политики, экономики, общественной жизни отражаются на языковых процессах, в том числе и в словообразовании. Социальными причинами на деривационном уровне стимулируются законы аналогии образования новых слов, экономии речевых средств и пр. Деривационные процессы занимают одну из ключевых позиций в процессе познания мира через единицы естественного языка, а самоё словообразование вполне следует рассматривать как систему обеспечения потребностей в выделении и фиксации особых структур (ментальных репрезентаций опыта и знаний человека). В результате протекания познавательных процессов язык постоянно обогащается и развивается, а продуцирование дериватов, прежде всего, обусловливает закрепление человеческого опыта, что приводит к отражению в словообразовательных единицах когнитивных результатов осмысления мира как языковой личностью, так и целым 
языковым сообществом. Сейчас успешно применяется в аспекте языковой синхронии именно динамический способ анализа производного слова, при котором наиболее важным фактом является теория действия моделей в тот или иной период развития языка, их продуктивность. Динамическое исследование словообразовательных отношений, возникающих между словообразующими единицами и составляющими их основу системными связями в дериватологии в рамках словообразовательных типов, словообразовательных гнезд / рядов и других объединений производных слов, позволяет понять потенциально процессуальные возможности самой системы [2; 3]. Несмотря на большие потенциальные возможности русской и украинской словообразовательной системы, наблюдаем развитие неузуального словообразования. В мощном потоке заимствований словообразовательные категории и типы не разрушаются, не модифицируются, что отражается в легком перерабатывании заимствованных лексем, в их адаптации к русской / украинской словообразовательной системе (выступают производящими, есть членами СГ, могут образовывать констелляции и аллигатуры, открытые СР). Ср.: рус. демпинг - демпинговый, антидемпинговый, демпинговать, демпингование, демпинговость; бренд брендировать, брендироваться, брендированныци, брендирование, забрендировать, брендовый, мультибрендовый; демпинг-политика, демпингстратегия, бренд-коммуникационный. Аналогичное в украинском языке. Среди политических неологизмов русского языка широкое употребление получили неологизмы, связанные с периодом зарождения и становления в России нового общественного строя и порядка в 90-е годы ХХ в. Так, с изменением политического строя появились слова: постсоветский, межправительственный, дебюрократизаџия, декриминализаџия, доперестроечный, доприватизационный, пиар, мажилисмен, маслихат, инаугурация; с переходом на рыночную экономику: хеджирование, евровалюта, бизнес-леди, оффшор; с расширением международной политики: саммит, глобализачия, нераспространение ядерного оружия, страна-изгой, большая восьмерка, планетарная этика, рашка, рашизм. Актуализировались трансноминанты. Например: наркозелье (наркотик), градоначальник (строитель), вахи (ваххабиты), триколор (флаг), криминал (преступление) и др. Небольшое количество трансноминантов в русском языке в общественно-политической сфере связано с тем, что современный русский язык еще формирует новый общественно-политический словарный запас и, главным образом, с помощью собственных ресурсов или через словообразование. Основной источник появления трансноминантов в русском языке в общественно-политической 
сфере - это политические эвфемизмы, так как традиционной сферой, в которой активно употребляются эвфемистические средства выражения, является дипломатическая деятельность. Среди политических неологизмов активизировалось образование слов, являющихся результатом вторичной номинации. Семантические неологизмы общественнополитической сферы русского языка чаще образуются с помощью всех известных видов семантических переносов: на основе метафоры; на основе метонимии; на основе расширения или сужения значения, а также семантического сдвига. Например: блокада - приостановка, задержка движения транспорта, перекрытие транспортных путей людьми в знак протеста; шоу (политическое) - выступления, дебаты политиков, направленные на привлечение масс, формирование выгодного общественного мнения; марафон - о каком-либо соперничестве, длительной и напряженной борьбе за лидерство в чем-либо (предвыборный, президентский марафон); дивиденды (политические) - преимущества в политической конкуренции; донор - организация, территория, за счет средств и продуктов производства которой существуют другие. Отличительной особенностью семантических неологизмов общественно-политического содержания в русском языке XXI века является преобладания изменений в сторону отрицательных оценок (кормушка, обвал, грабительский, коллапс и др.), в редких случаях в процессе становления нового значения происходят изменения нейтральной оценки на мелиоративную (подвижки, амортизатор и некоторые др.). Менее активен метонимический перенос, например: зеленые - участники общественного движения защиты окружающей среды; зеленые человечки - российские оккупационные войска, Беслан - захват заложников первого сентября 2004 года в одной из школ г. Беслан; Норд-Ocm - захват заложников в Москве во время показа мюзикла «Норд-Ост». Семантические неологизмы образуются в результате расширения значения, например, слова «nартиеи» в значении «рядовой член какой-либо партии, движения», «контекст» в значении «окружение, связи и отношения, влияющие на понимание тех или иных явлений, ситуаций и т. п.». К семантическим неологизмам, возникшим в результате сужения значения, относятся, например, квота в значении «установленное количество людей для нахождения, пребывания где-л.»; унитарный в значении «основанный на централизованном руководстве». Семантический сдвиг наблюдается, например, в ЛСВ команда в значении «лица, составляющие непосредственное окружение какого-либо деятеля, его советники, помощники, аппарат» (ср. команда - отряд, воинское подразделение), элита в значении «узкий круг людей, владеющих всей полнотой политической 
власти», а также «привилегированная верхушка общества или какой-то его части, какой-л. группы» (ср. элита - лучшие представители общества или какой-либо его части). От иноязычных основ активно образуются имена существительные с суффиксами -ник, -чик-/ -ичик-, -ец-/ -овец-, ucm-, -изм-, в украинском - -ник, -овець, -ісm-, -ізм-, употребление которых характерно для текстов СМИ и Интернета (ср. оффиморник / офшорник интернетчик, пиаровец / піарник, спамщик / спамник). Продуктивны модели с суффиксами -ств(о) и -ость: клипмейкерство, антикиллерство, брокерство, премьерство и др.; мультимедийность, суииидальность, рейтинговость и др. Растет число процессуальных существительных, образованных с помощью суффикса-ациј(a) / изаиј(a), минуя глагольную ступень, например, вестерн - вестернизация ('процесс изменения чего-либо по образу вестерна'); кластер кластеризация ('процесс разделения на кластеры'), буфер - буферизация ('процесс передачи данных в буфер обмена'). В сфере образования имен прилагательных наибольшую активность проявляют суффиксы -ск-, -ов/ -овск,-н-, в украинском -ськ-,-н-, -ов-: шенгенский / шенгенський, фольковый / фольковий, онлайновый / онлайний, пиаровский / піарний, интернетовский / інтернетний, гламурный / гламурний. Активизировалось взаимодействие с заимствованными основами и глагольных суффиксов, кроме -ирова-/ -уват, также -ова-,-и- (преимущественно в текстах Интернета и СМИ): брендировать, продюсировать, демпинговать, роуминговать, кастинговать, офиорить, мониторить. Можно говорить о первых признаках появления нового отрицательного префикса нон-, заимствованного из английского языка, хотя он встречается в немногочисленных словах с иностранными корнями, таких как нон-стоп нон-фикшн, нонконформизм, нонфактор, нонфакт, нонстандарт, конфигуративный. Активно стали развиваться и пополняться словообразовательные ряды с адаптацией форманта -мейкер, медиа- , apm и др., например: маркетмейкер или маркет-мейкер (market maker), имиджмейкер или имидж-мейкер (image maker), клипмейкер или клипмейкер (clip maker, clipmaker), суши-мейкер; пициа-мейкер, топикмейкер,матч-мейкер, файлмейкер, шоумейкер, климат-мэйкерь; медиагруппа, медиаимперия, медиакратия, медиамагнат, медиапартнерство, медиапокупка, медиапространство, медиа-профсоюз, медиарынок, медиасет; журналист, арт-заказник, арт-звезда, арт-инсталляция, арт-каталог, арт-кино, арт-клуб, арт-колледж, арт-конверсия, арткритика, арт-критик, арт-лицей, арт-место, арт-объект, арт-проект, арт-работа, арт-рынок; и др. На фоне возрастания общей словообразовательной активности увеличивается и образование новых слов от 
русских корней, прежде всего, за счет лакунарности русской словообразовательной системы и заполнения «пустых клеток» потенциально возможными производными.

\title{
Литература:
}

1. Резанова 3. И. Функциональный аспект словообразования: Русское производное имя. Томск: Изд-во Томского ун-та, 1996. 218 с.

2. Петрухина Е. В. Возможности, функции и конкуренты словопроизводства в современном русском языке. Новые явления 6 славянском словообразовании: система и функиионирование: Доклады XI Международной научной конференции Комиссии по славянскому словообразованию при Международном комитете славистов / Под ред. проф. Е. В. Петрухиной. Москва: Филологический факультет МГУ им. М.В. Ломоносова, 2010. - Режим доступа: https://www.portalslovo.ru/philology/45939.php

3. Скляревская Г. Н. Слово в меняющемся мире: русский язык начала XXI столетия: состояние, проблемы, перспективы. Исследования по славянским языкам. № 6. Сеул, 2001. С. 177-202.

DOI https://doi.org/10.30525/978-9934-26-073-5-1-19

\section{СЕМАНТИЧНІ ОСОБЛИВОСТІ ПОВНИХ ГОМОГЕННИХ МІЖМОВНИХ ОМОНІМІВ-ІМЕННИКІВ В УКРАЇНСЬКІЙ І БІЛОРУСЬКІЙ МОВАХ}

\author{
Щербина Д. В. \\ аспірант кафедри української мови \\ Криворізького державного педагогічного університету \\ м. Кривий Ріг, Дніпропетровська область, Україна
}

Інтенсивні контакти між двома мовами сприяють, з одного боку, їх обопільному збагаченню, а 3 другого - породжують небажану інтерференцію, яка найчастіше виявляється у відхиленні від норм однієї 3 мов під впливом іншої. Серед головних причин такої інтерференції міжмовна омонімія. Міжмовні омоніми становлять великі труднощі у практиці лексикографічної та перекладацької роботи або під час навчання іноземних мов, тож науковий інтерес до цієї багатогранної проблеми дедалі зростає. 